УДК 629.4.083

КРАШЕНІНІН О. С., Д-р техн. наук, проф.,

ОДЄГОВ М. М., старш. викл.,

СЕРБАЙ А. В., магістр,

РАДЦЕВ О. М., магістр

(Український державний університет залізничного транспорту)

\title{
Оцінка ризиків відмов обладнання локомотивів в експлуатації
}

На системи і обладнання локомотивів в експлуатації впливає значна кількість чинників, які, в комплексі діючи на роботу системи і обладнання, можуть призвести до ризикованих ситуацій, включаючи відмову. У статті розглядаються питання очінки ризиків відмов обладнання локомотивів. Так, показано, щзо надійна робота тягових електричних двигунів (ТЕД) залежить від ризиків роботи локомотива в складних умовах, зменшення швидкості нижче розрахункової та перевищення маси поїза більше за критичну. Для розрахунку ризиків відмови ТЕД розроблено алгоритм для прийняття рішень щзодо їх подальшої експлуатації.

Ключові слова: ризик, відмови, обладнання локомотивів, нечітка множина.

\section{Вступ}

Відмова технічної системи, наприклад локомотива, веде до значних витрат. Так, зупинка поїзда призводить до збою перевізного процесу і відповідно втрати часу на доставку вантажів чи пасажирів до місця призначення, витрат на усунення післядії відмови. Крім цього, в особливих випадках відмова може призвести до негативного впливу на навколишнє середовище.

При цьому величина втрат залежить від умов, в яких виникла відмова, і є подією випадковою.

Ризик (прийнята імовірність виникнення загрози життю людини, технічній системі, навколишньому середовищу, екології) $є$ невід'ємною частиною експлуатації технічних систем і одним із найважливіших показників безпеки.

У загальному розумінні ризиком називають можливість втрати через внутрішні аномалії в системі або аномалії середовища.

Для технічних систем при розрахунках застосовується характеристика математичного очікування ризику, значення якого визначається як множина втрат при виникненні небезпечної події на імовірність цієї події. Зважаючи на величину витрат, які можуть виникнути при відмові, визначення величини ризику є актуальним завданням, що постає в рамках забезпечення ефективності i безпеки експлуатації локомотивів.

\footnotetext{
Аналіз останніх досліджень і публікацій

Для управління ризиками розроблено методики, які зафіксовані в міжнародних (ISO), державних (ДСТУ) і галузевих стандартах.
}

() О. С. Крашенінін, М. М. Одсгов, А. В. Сербай, О. М. Радцев, 2021
В основі більшості методик застосовуються методи математичної статистики і теорії надійності $[1$, 4, 7]. Разом 3 цим при експлуатації ТРС $\epsilon$ характерним нечітке уявлення щодо граничних значень деяких параметрів i оцінки безпеки при перевищенні цих меж.

Теоретичні основи нечітких множин були запропоновані в роботах [2, 3], де чіткі границі були змінені на такі: «належить - не належить».

Останніми роками в нашій країні і за кордоном з'являється багато публікацій щодо практичного аспекту оцінки ризику функціонування різного обладнання локомотивів [5-7].

Зважаючи на сучасні реалії - старіння локомотивного парку і ремонтної інфраструктури оцінка можливого ризику експлуатації локомотивного парку набула значної актуальності і стає основою створення бази даних для управління надійністю локомотивного парку $[3,4,6]$.

\section{Визначення мети і завдання дослідження}

Мета статті полягає в розробленні процедури оцінки ризику відмови обладнання локомотивів на основі формування функції належності для нечітких множин.

Відповідно до реалізації мети дослідження поставлено такі завдання:

1. Визначити основні чинники, що впливають на виникнення ризику відмов обладнання локомотивів в експлуатації.

2. Оцінити діапазони дії чинників на ризик відмови обладнання локомотивів i розрахувати ризики за допомогою відповідного алгоритму.

3. Оцінити вплив розподілу діапазону чинників на величину ризику. 


\section{Основна частина дослідження}

Оскільки в експлуатації на будь-яку систему, зокрема обладнання локомотива, діє велика кількість чинників, урахувати вагу впливу яких немає можливості, доцільним є використання апарату теорії нечітких множин. У теорії нечітких множин основним показником $\epsilon$ нечітка множина А, яка задається множиною введених у неї елементів $x \in X$ і функцією належності $\mu_{A}(x)$ цих елементів до множини

$A=\left[x, \mu_{A}(x) \mid x \in X\right]$.
На прикладі покажемо ідею визначення ризику при експлуатації тягових електричних двигунів (ТЕД) локомотивів.

Спочатку розглянемо взаємозв'язок між швидкістю локомотива і характеристиками складності ділянки експлуатації та вагою поїзда $V=f_{1}\left(i_{1 i}, Q_{i}\right)$.

Так, на рис. 1 подано фрагмент швидкісної діаграми руху поїзда на розрахунковому ухилі для різних величин ваги поїзда, причому $Q_{1}>Q_{2}>Q_{3}$.

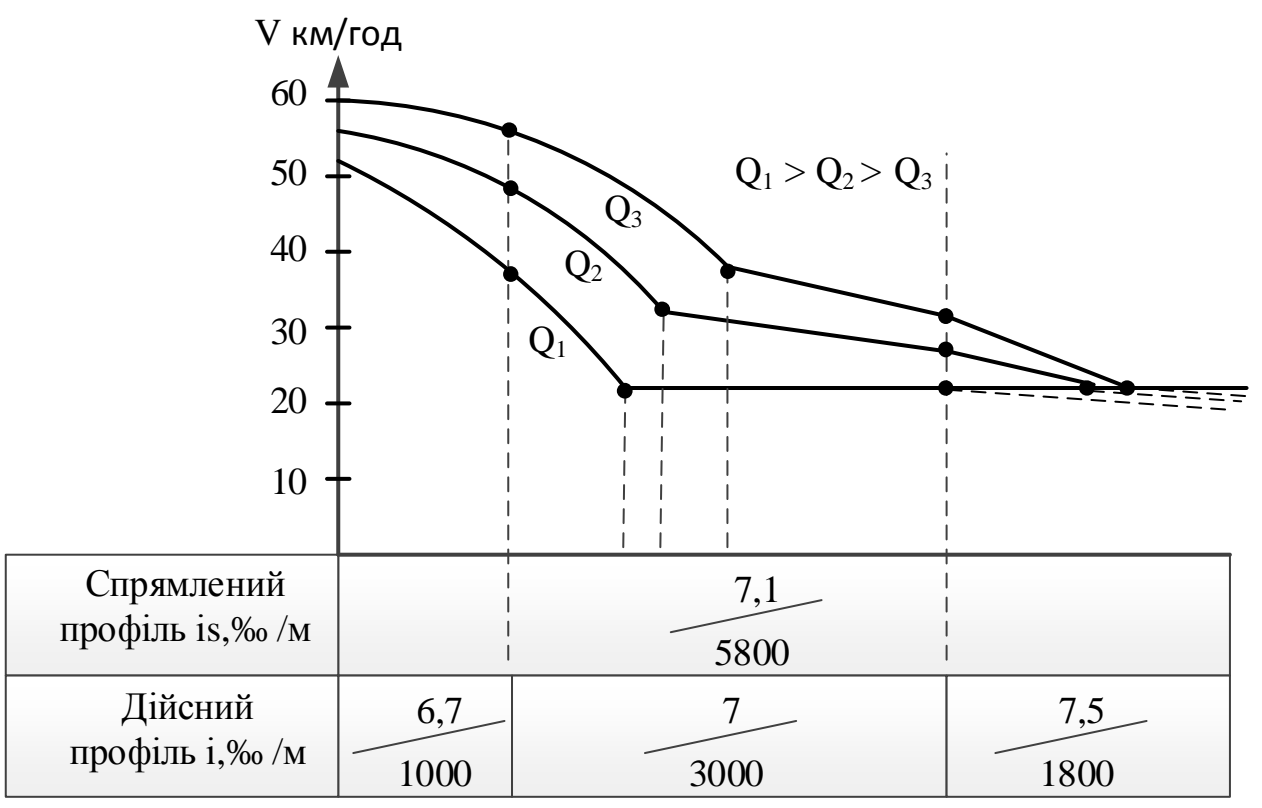

Рис. 1. Діаграма швидкості руху поїзда на розрахунковому ухилі ділянки

Для даного фрагмента розрахункове значення спрямленого ухилу дорівнює

$$
\begin{aligned}
i_{p} & =\frac{1000 \cdot 6,7+3000 \cdot 7+1800 \cdot 7,5}{1000+3000+1800}= \\
& =\frac{6700+21000+13500}{5800}=7,1^{0} \% .
\end{aligned}
$$

Як бачимо 3 наведеного на рис. 1 фрагмента спрямленої ділянки, для різних значень $Q_{i}$ ваги поїзда, який прийнято за матеріальну точку, досягнення розрахункової (рівноважної) швидкості руху на переламі ухилу на більш крутий супроводжується зменшенням швидкості пізніше або раніше нижче допустимої за надійності роботи ізоляції обмоток ТЕД.
Тобто при заході поїзда на ділянку $3 i_{p 3}>i_{p}$ швидкість може знижуватися до рівня меншого значення на розрахунковому (керівному) підйомі. Причому в цей період ТЕД локомотива працюють у перевантаженому режимі, що може призвести до перевищення допустимої температури перегріву ізоляції i створення ризику пробою ізоляції. Відношення довжини ділянок, де швидкість зменшується нижче розрахункової, до всієї довжини назвемо часткою (відсотком) складності ділянки.

Побудуємо зміну значень $V_{p}=f\left(i_{p}, Q_{i}=\right.$ const $)$ для різних значень ваги поїзда на деякій ділянці при різних значеннях $i_{p i}$ (рис. 2). 


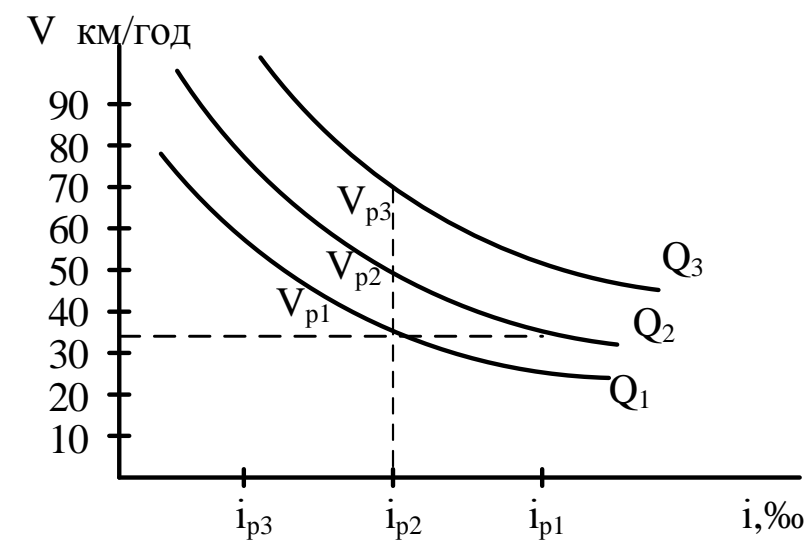

Рис. 2. Залежність $V_{p}=f\left(i_{p}, Q_{i}=\right.$ const $), Q_{1}>Q_{2}>Q_{3}$

Формування бази даних для оцінки ризику при русі поїзда в перевантаженому режимі дасть змогу сформувати формальну модель зміни величини ризику від відсотка довжини ділянки, де допускається цей ризик.

Це окрема задача, i в рамках статті не розглядається. Для ілюстрації використання цієї інформації задаємось такими умовами: при відсотку $\delta=30 \%$ дослідної ділянки, де знижується швидкість нижче розрахункової, приймаємо функцію належності $\mu_{A}(\delta)=0$ при відсотку $30 \%<\delta \%<70 \%$ - лінійну залежність функції належності ризику $\mu_{A}(\delta)=2,5\left(\frac{\delta-30}{100}\right)$, а при $\delta \%>70 \%$ функція належності дорівнює $\mu_{A}(\delta)=1$, тобто ризик максимальний. Графік цієї залежності подано на рис. 3.

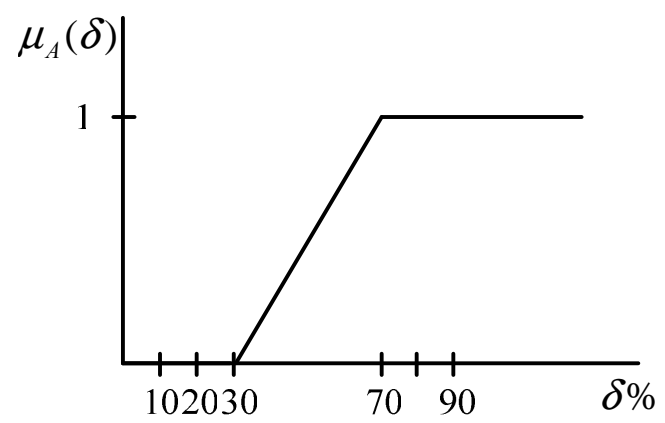

Рис. 3. Зміна значення функції належності

$$
\mu_{A(\delta)}=f(\delta)
$$

Тобто в загальному вигляді ця функція має вигляд:

$$
\mu_{A(\delta)}=\left\{\begin{array}{cl}
0 & \text { при } \delta \%<30 \% \\
2,5\left(\frac{\delta-30}{100}\right) & \text { при } 30 \%<\delta \%<70 \% ; \\
1 & \text { при } \delta \%>70 \%
\end{array}\right.
$$

Аналогічно прийнято значення виникнення ризику $R$ при перевезенні різної ваги поїздів у такому діапазоні: $Q<4000 m$ функція належності $\mu_{B(Q)}=0$, при $4000<Q<6000$ лінія функції належності має вигляд $\mu_{B(Q)}=5\left(\frac{\delta-4000}{10000}\right)$, а при $Q>6000-\mu_{B(Q)}=1$.

Отже, залежність $\mu_{B(Q)}$ має вигляд:

$$
\mu_{B(Q)}=\left\{\begin{array}{c}
0 \quad \text { при } Q<4000 m ; \\
5\left(\frac{\delta-4000}{10000}\right) \text { при } 4000 m<Q<6000 m ; \\
1 \quad \text { при } Q>6000 m .
\end{array}\right.
$$

Графічно це зображено на рис. 4 , а. 
a

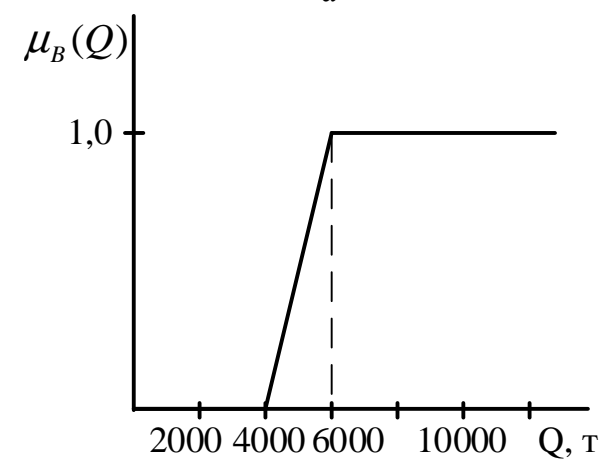

б

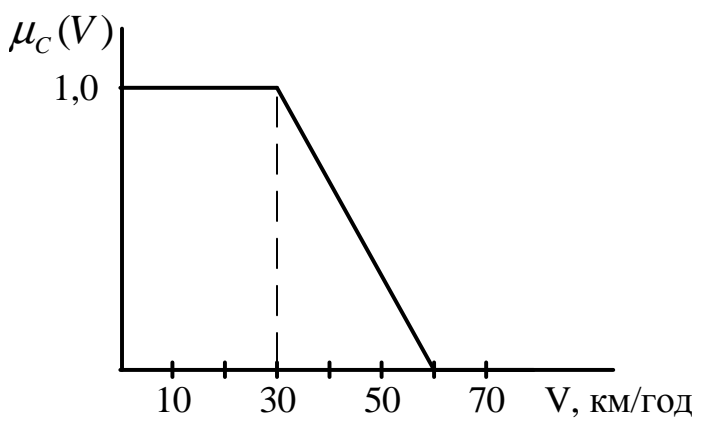

Рис. 4. Зміна значення функції належності: а - в діапазоні ваги поїздів; б - у діапазоні швидкостей

Аналогічно на рис. 4, б наведено графік функції належності $\mu_{C(V)}$ від швидкості руху

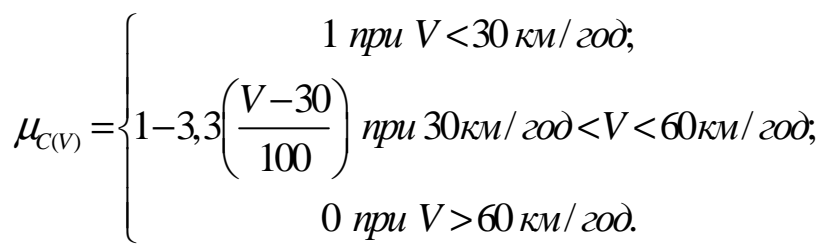

Тоді логічне твердження, що вантажний поїзд вагою $Q \quad\left(A=\left[\left(Q_{i}, \mu_{A}\left(Q_{i}\right)\right) \mid Q_{i} \in Q\right]\right)$ пройде керівний підйом $i_{p}\left(B=\left[\left(\delta_{i}, \mu_{B}\left(\delta_{i}\right)\right) \mid \delta_{i} \in \delta\right]\right)$ зі швидкістю $V$, що нижче розрахункової $V_{p}$ $\left(C=\left[\left(V_{i}, \mu_{C}\left(V_{i}\right)\right) \mid V_{i} \in V\right]\right), \quad$ буде визначати ризик відмови ТЕД за формулою $R=\mu_{A}\left(\delta_{i}\right) \cdot \mu_{B}\left(Q_{i}\right) \cdot \mu_{C}\left(V_{i}\right), \quad$ який $\quad$ може змінюватися від 0 до 1 (або $100 \%$ ). Так, наприклад, коли поїзд масою 3000 т прямує на керівному підйомі зі швидкістю 70 км/год, ризик відмови ТЕД дорівнюе $R=0 \cdot 0 \cdot 0=0$.
Навпаки, коли поїзд масою $Q$, більшою за 6000 т, прямує по керівному підйому зі швидкістю $V$, меншою за 30 км/год, ризик виникнення відмов ТЕД дорівнюе $R=1 \cdot 1 \cdot 1=1$ (або $100 \%)$.

А при масі 5000 т зі швидкістю 50 км/год і $40 \%$ керівного підйому ризик відмови ТЕД складає: $R=0,5 \cdot 0,33 \cdot 0,25=0,04125$.

За нестабільної ситуації, коли при проходженні по керівному підйому порушувався режим ведення поїзда кілька разів, ризик відмови ТЕД визначається за формулою оцінки ризику для паралельного з'єднання.

$$
\mathrm{R}=1-\prod_{i=1}^{u}\left(1-R_{i}\right)
$$

Для зручності розрахунків ризику розроблено структурну схему алгоритму визначення ризику (рис. 5), який можна реалізувати для забезпечення підтримки надійності електричних машин.

Слід зазначити, що за поданою моделлю можна оцінити ризики, що обумовлені іншими чинниками, що впливають на відхилення від надійної роботи обладнання. Наприклад, при пробуксовуванні колісної пари $\epsilon$ ризик виникнення колового вогню по колектору, а при неякісній технології сушіння обмоток ТЕД $є$ ризик пробою ізоляції. Ці чинники осягають більш широкий спектр чинників, що охоплює сферу якості експлуатації локомотивів локомотивною бригадою та сферу організації ремонту. 


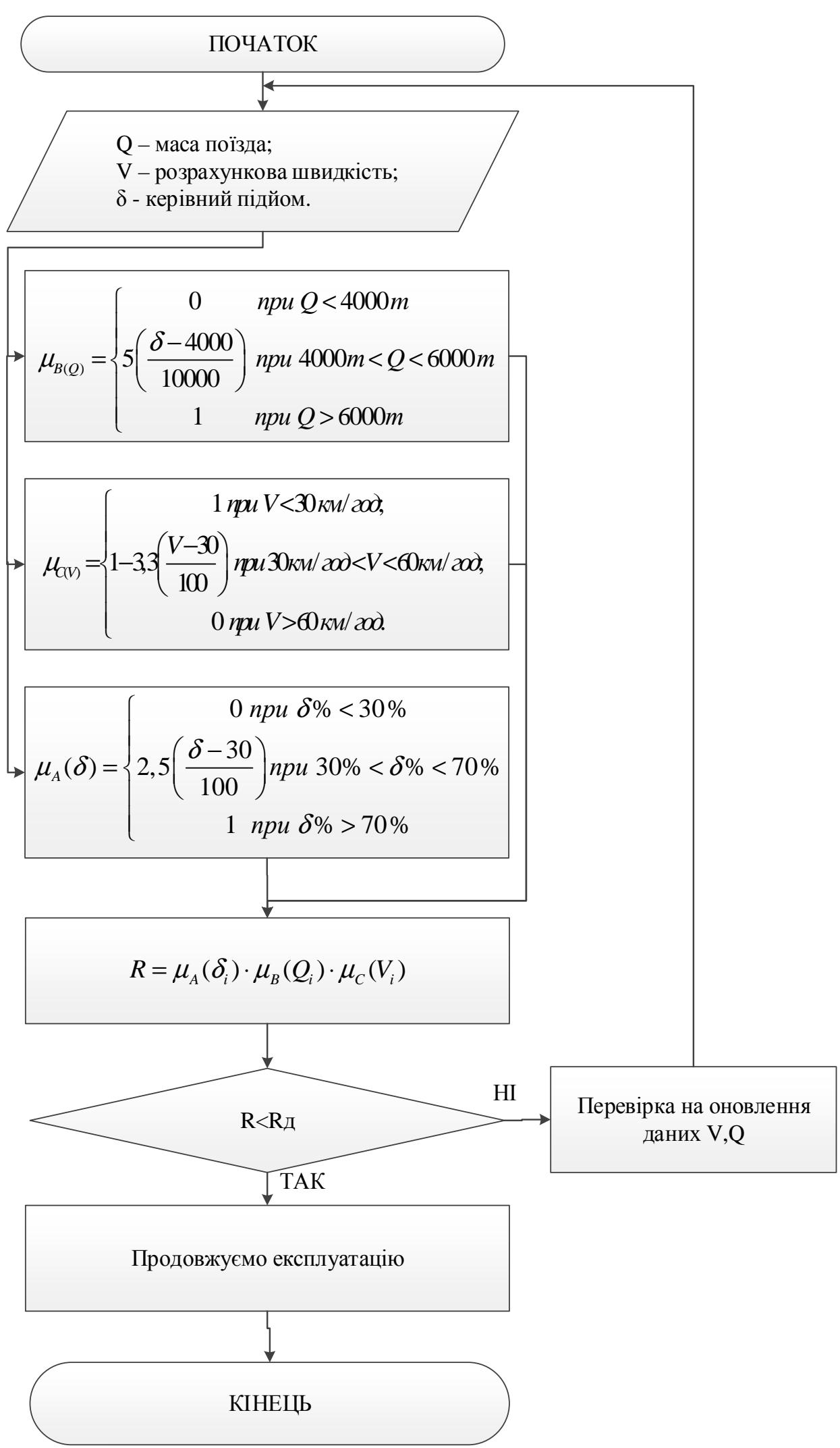

Рис. 5. Структурна схема визначення ризику відмови ТЕД 


\begin{tabular}{l} 
Висновки \\
\hline 1. Основними чинниками, що визначають \\
можливість ризику відмов обладнання локомотивів в \\
експлуатації, доцільно обирати: складність ділянки \\
експлуатації, вагу поїзда, швидкість руху поїзда. Саме \\
комплекс дії цих чинників виключає ризик відмов \\
обладнання. \\
2. За даними експертних оцінок і досвіду \\
експлуатації визначено відповідні діапазони розподілу \\
величини ризиків і визначено математичні залежності \\
для їх графічного зображення. \\
3. При уточненні розподілу величин ризиків для \\
різних чинників доцільно долучати статистичні дані \\
або експертні оцінки з урахуванням конкретних умов \\
експлуатації. Залучення цих даних дозволить всебічно \\
оцінювати ризики відмов обладнання локомотивів.
\end{tabular}

Список використаних джерел

1. Krasheninin O., Klymenko O., Ponomarenko O., Yakovlev S. (2018) Justification of statutory service life extension of locomotives on the basis of theory of aging. International Journal of Engineering \& Technology. № 7 (43). Р. $174-178$.

2. Конышева Л. К., Назаров Д. М. Основы теории нечетких множеств. Санкт-Петербург: Питер, 2011. 192 c.

3. Кофман А. Введение в теорию нечетких множеств. Москва: Радио и связь, 1982. 432 с.

4. Методы оценки жизненного цикла тягового подвижного состава железных дорог: монографія / Э. Д. Тартаковский, С. Г. Грищенко, Ю. Е. Калабухин, А. П. Фалендыш. Луганск: Издво «Ноулидж», 2011. 174 с.

5. Канарчук В. С., Полянський С. К., Дмитрієв М. М. Надійність машин: підручник. Київ: Либідь, 2003. $424 \mathrm{c.}$

6. Козлов Б. А., Ушаков И. А. Справочник по расчету надежности аппаратуры радиотехники и автоматики. Москва: Советское радио, 1975. 472 с.

7. Половко А. М., Гуров С. В. Основы теории надежности. Практикум. Санкт-Петербург: БХВ Петербург, 2006. 560 с.

\footnotetext{
A. Krasheninin, M. Odiehov, A. Serbai, O. Radtsev. Risk assessment of locomotive equipment failures in operation.

Abstract. The systems and equipment of locomotives in operation are affected by a significant number of factors that in combination with the operation of the system and equipment can lead to risky situations, including failure. Failure of a technical system, such as a locomotive, leads to significant costs. Thus, the stop of the train leads to the failure of the transportation process and, accordingly, the loss of time for delivery of goods or passengers to the destination, the cost of eliminating the aftermath of the
}

refusal. In addition, in special cases, failure can have a negative impact on the environment. The amount of loss depends on the conditions in which the failure occurred, and is an accidental event. The article considers the issues of risk assessment of locomotive equipment failures. For technical systems, the calculations use the characteristic of the mathematical expectation of risk, the value of which is defined as the set of losses in the event of a dangerous event on the probability of this event. Based on the amount of costs that may arise in case of failure, determining the amount of risk is an urgent task that arises in the framework of ensuring the efficiency and safety of locomotives. In particular, it is shown that the reliable operation of traction electric motors (TED) depends on the risks of locomotive operation in difficult conditions, reducing the speed below the design and exceeding the mass of the train more critical.

For risk management the methods which are fixed in the international (ISO), state (DSTU) and branch standards are developed. Most methods are based on methods of mathematical statistics and reliability theory. However, in the operation of TRS is characterized by a vague idea of the limit values of some parameters and safety assessment in excess of these limits. To calculate the risks of TED failure, an algorithm has been developed to make decisions on their further operation. The use and assessment of the risk of equipment failure in any situation allows you to make the right decisions to ensure reliable operation of the equipment. The considered technique can be adjusted on condition of specification of the law of distribution of risk at transition from 0 or 1 intermediate characteristics of the considered parameter on condition of use of statistical data or expert estimations.

Keywords: risk, failures, locomotive equipment, fuzzy set.

Надійшла 23.04.2021 p.

Крашенінін Олександр Семенович, д-р техн. наук, професор кафедри експлуатації та ремонту рухомого складу Украӥнського державного університету залізничного транспорту. ORCID iD: 0000-0001-74623372.E-mail: krasheninin@kart.edu.ua.

Одєгов Микола Миколайович, старший викладач кафедри електроенергетики, електротехніки та електромеханіки Українського державного університету залізничного трансnорту. ORCID iD: 0000-0003-3967-9009. E-mail: odegov@kart.edu.ua.

Сербай Андрій Володимирович, магістр, група 213ЛЛГ-319 Украӥнського державного університету залізничного транспорту.

Радцев Олексій Михайлович, магістр, група 211ЛЛГ-Д19 Українського державного університету залізничного транспорту. 
A. Krasheninin, Dr. Sc. (Tech.) professor, department of maintenance and repair of rolling stock, Ukrainian State University of Railway Transport. ORCID iD: 0000-00017462-3372. Tel.: +38 (057) 730-19-99. E-mail: krasheninin@kart.edu.ua.

M. Odiehov, Senior Lecturer, department of electric power, electrical engineering and electromechanics, Ukrainian State University of Railway Transport. ORCID iD:0000-0003-3967-9009. E-mail: odegov@kart.edu.ua.

A. Serbai, master, Group 213-ЛЛГ-319, Ukrainian State University of Railway Transport.

O. Radtsev, master, Group 213-ЛЛГ-319, Ukrainian State University of Railway Transport. 